УДК 631.11: 632.4

ЕФЕКТИВНІСТЬ СУЧАСНИХ ФУНГІЦИДІВ ПРОТИ ЖОВТОЇ ІРЖІ

(PUCCINIA STRIIFORMIS WEST. F. SP. TRITICI ERIKSS. ET HENN) HA

ОЗИМІЙ ПШЕНИЦІ У ПІВДЕННОМУ СТЕПУ УКРАЇНИ

Н. М. ЧУСОВІТІНА, молодший науковий співробітник

Інститут овочівництва і бачтанництва НАAН

E-mail: kalashnik-natawa@mail.ru

Л. В. НЕПЛІЙ, кандидат біологічних наук

Селекційно-генетичний інститут - Національній центр насіннєзнавства

та сортовивчення НААН

E-mail: ludawka-24@mail.ru

\author{
М. А. ЗАЛОГІНА-КИРКЕЛАН, \\ Науково-виробнича фірма «ФУНГІ-ЕКО» \\ E-mail: phyto_lab@ukr.net
}

\begin{abstract}
Анотація. За останні роки на Півдні України все частіше відмічаються спалахи жовтої іржі. Основними факторами, які сприяють розвитку хвороби $\epsilon$ м'яка зима, волога прохолодна весна, прояв хвороби у попередньому році, наявність падалиці, засміченість посівів злаковими бур'янами та, головне, вирощування сприйнятливих до жовтої іржі сортів. Найбільш дієвим комплексним заходом попередження епіфітотій жовтої іржі $\epsilon$ пошук $i$ застосування високоефективних фунгіцидів. За периих проявів хвороби необхідно їх застосовувати з метою недопущення масового розповсюдження патогену. Високоефективні фунгіциди, збільшуючи валовий урожай зерна, покрашують також і його якість.

Аналізуючи ефективність дії досліджуваних препаратів проти збудника жовтої іржі на озимій пшениці у двох варіантах обробки було виявлено, щуо у не епіфтотійні роки жовтої іржі варто застосовувати препарати Аканто Плюс $1.5 \pi / 2 a$, Ракурс 0.7 л/га, Спіріт 0.7 л/га, оскільки інтенсивність ураження була мінімальною, а урожайність тим часом найвищою.

В епіфітотійні роки жовтої іржі на озимій пшениці варто застосовувати препарати Спіріт 0, 7 л/га, оскільки у иььму варіанті уредініоспори були відсутні на рослинах озимої пшениці, а урожайність - максимальною.
\end{abstract}

Ключові слова: озима пшениия, жовта іржа, фунгіщид, інокулячія

В Україні виробництво зерна - важлива галузь рослинництва. Перше місце, як найбільш цінна та високоврожайна продовольча зернова культура, 
займає озима пшениця. Одним 3 найбільш шкідливих захворювань цієї культури є жовта іржа Puccinia striiformis West. f. sp. tritici Erikss. et Henn. Іржасті гриби зменшують фотосинтез, прискорюють дихання та випаровування, що суттєво впливає на урожайність та якість зерна [1, с. 3].

Аналіз останніх досліджень та публікацій Навіть за середнього ступеню ураження хворобою втрати врожаю складають 20-50\% [2, с. 216]. За появи збудника в осінній період, успішної перезимівлі та розвитку у вегетаційний сезон можна очікувати 100 \% втрати врожаю [3, с. 121]. За останні роки на Півдні України все частіше відмічаються спалахи жовтої іржі. Основними факторами, що сприяють розвитку хвороби є м'яка зима, волога прохолодна весна, проявлення хвороби у попередньому році, наявність падалиці, засміченість посівів злаковими бур'янами та, головне, вирощування сприйнятливих до жовтої іржі сортів. [4, с. 93].

Найважливішим елементом інтегрованого захисту пшениці від іржастих хвороб є вирощування стійких до цих збудників сортів. Щоб успішно керувати патосистемою «господар-патоген» необхідно в агроекосистемах підтримувати різноманіття за ознакою стійкості як у часі, так і в просторі з урахуванням структури патогена в середині популяції. [5, с. 256] Однак найбільш дієвим комплексним заходом попередження епіфітотій жовтої іржі $\epsilon$ пошук i застосування високоефективних фунгіцидів. За перших проявів хвороби необхідно їх застосовувати, щоб не допустити масового розповсюдження патогену. Високоефективні фунгіциди, збільшуючи валовий урожай зерна, покращують також і його якість [6].

В Одеській області у 2015 році на посівах пшениці спостерігався розвиток жовтої іржі. Епіфітотії цієї хвороби (інтенсивність ураження 40-100 \%) спостерігалися на сприйнятливих сортах та лініях Лузанівка, Застава, Знахідка Одеська, Селянка, Литанівка, Господиня одеська, Годувальниця одеська, Служниця одеська, Епоха одеська, Ватажок, Журавка одеська, Heines VII, Scarlet, Avocet. 
Враховуючи все вище викладене зрозуміло, що всебічне дослідження шкідливості жовтої іржі та шляхів їі подолання є вельми актуальним.

Мета дослідження - визначення ефективності сучасних фунгіцидів у епіфітотійний та неепіфітотійний роки проти жовтої іржі.

Матеріали і методи дослідження. Протягом 2013-2015 pp. у польовому інфекційному розсаднику на фоні природної і штучної інфекції жовтої іржі у сівозміні пар - озима пшениця вивчали дію сучасних фунгіцидів проти жовтої іржі у Південному Степу України. Дослід закладали на озимій пшениці сорту Лузанівка (індикатор сприйнятливості до збудника жовтої іржі). Всі досліджувані фунгіциди входять до «Переліку пестицидів та агрохімікатів, дозволених до використання в Україні» препаратів, що дозволені для використання на території України. Норма висіву насіння складала 4,5 млн шт./га. Дослід закладали у триразовій повторності ділянками площею $10 \mathrm{~m}^{2}$ у двох варіантах обробки. Перший - на фоні природної епіфітотійної інфекції жовтої іржі навесні 2013 - 2015 pp. і через 4 доби застосували досліджувані фунгіциди, ще через 2 доби штучно інокулювали рослини концентрацією урединіоспор із тальком $(1: 100)$ [5, с. 211]. Інфекційне навантаження на $1 \mathrm{~m}^{2}$ посіву складало 30 мг схожих спор. Другий - штучно уражували рослини концентрацією уредоспор жовтої іржі, через 4 дні застосували різни фунгіциди. Контролем слугував варіант без застосування фунгіцидів (табл. 1). 
1. Варіанти обробок рослин озимої пшениці проти жовтої іржі у посівах 2013 - 2014 та $2014-2015$ pp.

\begin{tabular}{|c|c|c|c|c|c|}
\hline \multirow[b]{2}{*}{$\begin{array}{l}\text { № } \\
\text { З.П. }\end{array}$} & \multicolumn{5}{|c|}{ І варіант застосування фунгіцидів } \\
\hline & Фунгіциди & $\begin{array}{l}\text { Норма, } \\
\text { л/га }\end{array}$ & \multirow{6}{*}{$\begin{array}{c}\text { Природна } \\
\text { епіфітотійна } \\
\text { інфекція } \\
\text { жовтої іржі }\end{array}$} & \multirow{6}{*}{$\begin{array}{c}\text { Через } 4 \text { доби } \\
\text { застосували } \\
\text { досліджувані } \\
\text { фунгіциди }\end{array}$} & \multirow{6}{*}{$\begin{array}{c}\text { Через } 2 \text { доби } \\
\text { штучно } \\
\text { інокулювали } \\
\text { уредоспорами } \\
\text { жовтої іржі }\end{array}$} \\
\hline 1. & Бампер Супер & 1,0 & & & \\
\hline 2. & Суприм 400 & 1,125 & & & \\
\hline 3. & Вареон & 0,8 & & & \\
\hline 4. & Аканто Плюс & 1,5 & & & \\
\hline 5. & Старпро & 0,6 & & & \\
\hline 6. & Титул Дуо & 1,0 & & & \\
\hline 7. & Евіто T & 0,7 & & & \\
\hline 8. & Медісон & 1,0 & & & \\
\hline 9. & Абакус & 0,3 & & & \\
\hline 10. & Авіатор Хро & 0,9 & & & \\
\hline 11. & Імпакт T & 0,8 & & & \\
\hline 12. & Імпакт 500 & 0,25 & & & \\
\hline 13. & Ракурс & 0,7 & & & \\
\hline 14. & Спіріт & 0,7 & & & \\
\hline 15. & Солігор & 0,8 & & & \\
\hline \multirow[t]{3}{*}{16.} & \multicolumn{5}{|c|}{$\begin{array}{l}\text { Контроль - без застосування фунгіцидів, але із штучною інокуляцією спорами } \\
\text { жовтої іржі }\end{array}$} \\
\hline & \multicolumn{5}{|c|}{ II варіант застосування фунгіцидів } \\
\hline & Фунгіциди & $\begin{array}{l}\text { Норма, } \\
\text { л/га }\end{array}$ & \multirow{16}{*}{$\begin{array}{c}\text { Штучно } \\
\text { інокулювали } \\
\text { уредоспорами } \\
\text { жовтої іржі }\end{array}$} & \multirow{16}{*}{$\begin{array}{c}\text { Через } 4 \text { доби } \\
\text { застосували } \\
\text { досліджувані } \\
\text { фунгіциди }\end{array}$} & \\
\hline 1. & Бампер Супер & 1,0 & & & \\
\hline 2. & Суприм 400 & 1,125 & & & \\
\hline 3. & Bapeoн & 0,8 & & & \\
\hline 4. & Аканто Плюс & 1,5 & & & \\
\hline 5. & Старпро & 0,6 & & & \\
\hline 6. & Титул Дуо & 1,0 & & & \\
\hline 7. & Евіто T & 0,7 & & & \\
\hline 8. & Медісон & 1,0 & & & \\
\hline 9. & Абакус & 0,3 & & & \\
\hline 10. & Авіатор Хро & 0,9 & & & \\
\hline 11. & Імпакт T & 0,8 & & & \\
\hline 12. & Імпакт 500 & 0,25 & & & \\
\hline 13. & Ракурс & 0,7 & & & \\
\hline 14. & Спіріт & 0,7 & & & \\
\hline 15. & Солігор & 0,8 & & & \\
\hline 16. & $\begin{array}{l}\text { Контроль - без } \\
\text { жовтої іржі }\end{array}$ & Іня фун! & дів, але із шту & ою інокуляцієң & спорами \\
\hline
\end{tabular}

У травні 2013 - 2015 рр. проводили оцінку ефективності досліджуваних препаратів проти жовтої іржі. Інтенсивність ураження жовтою іржею озимої пшениці прапорцевого та підпрапорцевого листків оцінювали за шкалою Петерсона. [3, с. 315] Весною для захисту посівів від бур'янів у фазу кущення 
застосували гербіцид Гроділ Максі (0,09 л/га). У фазі молочно-воскової стиглості (фаза ВВСH83 (J. Zadoks) обробляли ділянки проти клопа шкідливої черепашки та інших шкідників колосу препаратом Коннект (0,5 л/га). Штучне інокулювання рослин озимої пшениці урединіоспорами жовтої іржі проводили у фазу початку трубкування, рано вранці шляхом обпилювання рослин сумішшю урединіоспор гриба $P$. striiformis із тальком (1:100). Для інокуляції використовували урединіоспоровий матеріал, зібраний у польовому інфекційному розсаднику минулого року. Інфекційне навантаження на 1 м $^{2}$ посіву склало 30 мг схожих спор. Інокульовані рослини ізолювали ізоляторами, які знімали наступного дня вранці. Другу інокуляцію проводили у фазу трубкування водною суспензією урединіоспор (100 мг спор на 100 мг води) за допомогою шприца безперервної дії «Рекорд Ш-19».

Після появи урединіоспор проводили окомірні обліки (від трьох до п’яти) інтенсивності ураження рослин за шкалою Кобба [7, с. 164], типів реакції на інфекцію патогена - за шкалою Gassner i Straib, [7, с. 170] ступінь стійкості та сприйнятливості - за шкалою, розробленою фітопатологами PEB [7, с. 178]. Математичне опрацювання результатів проводили за загальноприйнятими методами варіаційної статистики П. Ф. Рокицького [8, с. 179]. Біологічну ефективність підраховували за формулою:

$$
\text { Беф }=((П к-\text { По }) / \text { Пк) х } 100 \%,
$$

де Пк - кількість рослин у контрольному варіанті, По - кількість рослин у дослідному варіанті.

Результати дослідження та їх обговорення. В роки досліджень на території України на посівах пшениці спостерігалась масова епіфітотія жовтої іржі. Особливо вона проявилась на півдні України на озимій пшениці. Інтенсивність ураження сортів одеської селекції варіювала від 2 до $45 \%$. У зв'язку з цим за мету визначили вивчення ефективності сучасних фунгіцидів у епіфітотійний рік. Розглядаючи інтенсивність ураження жовтою іржею на I варіанті на прапорцевому листку протягом 2013 - 2014 pp. (табл. 2) нами було помічено, що мінімальна інтенсивність ураження 
спостерігалась на варіантах Аканто Плюс 1,5 л/га, Абакус 0,3 л/га, Ракурс 0,7 л/га та Спіріт 0,7 л/га і становила 0,5-0,7 \%. Найвище значення інтенсивності ураження спостерігалось на варіанті Титул Дуо 1,0 л/га (16,8 $\%$ ), дещо йому поступився варіант Медісон 1,0 л/га (11,5\%). Останні варіанти зайняли проміжне положення за цим показником. На контролі рівень розвитку жовтої іржі становив 38,0 \%. На II варіанті, аналізуючи інтенсивність ураження рослин жовтою іржею на прапорцевому листку протягом 2014 - 2015 рр, нами було помічено, що відсутність жовтої іржі спостерігалась на варіанті Аканто Плюс 1,5 л/га (0 \%). Максимальне значення спостерігалось у варіанті Титул Дуо 1,0 л/га і становило 16,3\%. Останні варіанти зайняли проміжне положення за цим показником. На контролі розвиток жовтої іржі становив $20 \%$. Аналізуючи інтенсивність ураження озимої пшениці жовтою іржею на I варіанті передпрапорцевого листка протягом 2013 - 2014 рр. нами було помічено, що відсутність жовтої іржі спостерігалась на варіантах Суприм 400 1,125 л/га та Вареон 0,8 л/га (0 \%), дещо їм поступився варіант Аканто Плюс 1,5 л/га (1 \%). Найбільше ураження жовтою іржею спостерігалось на варіантах Евіто 0,7 л/га та Медісон 1,0 л/га (40,5 \%), дещо їм поступився варіант Абакус 0,3 л/га $(35,0 \%)$. На контролі розвиток жовтої іржі становив на рівні $52 \%$. Майже аналогічна ситуація спостерігалась на I варіанті на передпрапорцевому листку протягом 2014 - 2015 pр. Але на контролі розвиток жовтої іржі становив на рівні $60 \%$. Розглядаючи інтенсивність ураження жовтою іржею на II варіанті на прапорцевому листку протягом 2013 - 2014 рр. нами було помічено, що відсутність жовтої іржі спостерігалось на варіантах Ракурс 0,7 л/га та Спіріт 0,7 л/га (0 \%), дещо їм поступились варіанти Авіатор Хро 0,9 л/га, Імпакт Т 0,8 л/га та Аканто Плюс 1,5 л/га (0,5 \%). Найвище значення інтенсивності ураження спостерігалось на варіантах Бампер Супер 1,0 л/га та Титул Дуо 1,0 л/га і становив відповідно 16,5 та 12 \%. На контролі розвиток жовтої іржі становив $40 \%$. Майже аналогічна ситуація спостерігалась на II варіанті на прапорцевому листку протягом 2014 - 2015 
pp. На контролі цьому тим часом розвиток інфекції становив 30 \%. Аналіз розвитку жовтої іржі на II варіанті на передпрапорцевому листку показав відсутність інфекції на варіантах Ракурс 0,7 л/га та Спіріт 0,7 л/га (0 \%), дещо їм поступився варіант Авіатор Хро 0,9 л/га (0,5 \%). Найвище значення жовтої іржі спостерігалось на варіанті Бампер Супер 1,0 л/га (49 \%). Останні варіанти зайняли проміжне положення за цим показником. На контролі розвиток жовтої іржі становив 55 \%. Близька ситуація спостерігалась на II варіанті на передпрапорцевому листку протягом 2014 - 2015 pp. - 60 \% на контролі. Таким чином, проаналізувавши ефективність дії препаратів на I та II варіантах обробки на прапорцевому і передпрапорцевому листках, нами встановлено: на I і II варіантах високоефективним виявився препарат Аканто Плюс 1,5 л/га, оскільки інтенсивність ураження виявилась найменшою; на II варіанті аналогічну дію показав препарат Ракурс 0,7 л/га, оскільки пустул жовтої іржі нами не було помічено взагалі. Дещо їм поступились препарати Авіатор Хро 0,9 л/га та Імпакт Т 0,8 л/га. Про це свідчать і значення біологічної ефективності препаратів, що наведені у таблиця 3. 
2. Інтенсивність ураження озимої пшениці жовтою іржею прапорцевого та передпрапорцевого листків у двох варіантах обробки фунгіцидами, посіви 2013 - 2014 та 2014 - 15 pp.

\begin{tabular}{|c|c|c|c|c|c|c|c|c|c|c|}
\hline \multirow{4}{*}{$\begin{array}{l}\text { № } \\
\text { 3.П. }\end{array}$} & \multirow{4}{*}{ Фунгіциди } & \multirow{4}{*}{$\begin{array}{c}\text { Норма, } \\
\text { л/га }\end{array}$} & \multicolumn{8}{|c|}{ Інтенсивність ураження рослин жовтою іржею, \% } \\
\hline & & & \multicolumn{4}{|c|}{ I-варіант } & \multicolumn{4}{|c|}{ II-варіант } \\
\hline & & & \multicolumn{2}{|c|}{$\begin{array}{l}\text { Прапорцевий } \\
\text { листок }\end{array}$} & \multicolumn{2}{|c|}{$\begin{array}{c}\text { Передпрапорцевий } \\
\text { листок }\end{array}$} & \multicolumn{2}{|c|}{$\begin{array}{c}\text { Прапорцевий } \\
\text { листок }\end{array}$} & \multicolumn{2}{|c|}{$\begin{array}{c}\text { Передпрапорцевий } \\
\text { листок }\end{array}$} \\
\hline & & & $\begin{array}{c}2014- \\
2015\end{array}$ & $\begin{array}{c}2013- \\
2014\end{array}$ & $2014-2015$ & $2013-2014$ & $\begin{array}{c}2014- \\
2015\end{array}$ & $2013-2014$ & 2014- 2015 & $2013-2014$ \\
\hline 1. & Бампер Супер & 1,0 & $5,0 \pm 0,2$ & $5,5 \pm 0,3$ & $5,0 \pm 0,2$ & $6,5 \pm 0,3$ & $15,5 \pm 1,4$ & $16,5 \pm 1,4$ & $50,0 \pm 4,3$ & $49,0 \pm 4,3$ \\
\hline 2. & Суприм 400 & 1,125 & $2,5 \pm 0,1$ & $2,8 \pm 0,2$ & $0,0 \pm 0$ & $0,0 \pm 0$ & $2,5 \pm 0,1$ & $3,5 \pm 0,2$ & $5,0 \pm 0,2$ & $6,0 \pm 0,3$ \\
\hline 3. & Bapeoн & 0,8 & $2,5 \pm 0,1$ & $2,8 \pm 0,2$ & $0,0 \pm 0$ & $0,0 \pm 0$ & $5,5 \pm 0,3$ & $6,5 \pm 0,3$ & $3,7 \pm 0,3$ & $4,7 \pm 0,3$ \\
\hline 4. & Аканто Плюс & 1,5 & $0,0 \pm 0$ & $0,5 \pm 0,01$ & $0,5 \pm 0,01$ & $1,0 \pm 0,1$ & $0,5 \pm 0,01$ & $0,5 \pm 0,01$ & $5,0 \pm 0,2$ & $5,0 \pm 0,2$ \\
\hline 5. & Старпро & 0,6 & $2,0 \pm 0,1$ & $2,5 \pm 0,1$ & $26,3 \pm 1,9$ & $26,6 \pm 1,9$ & $2,5 \pm 0,1$ & $3,5 \pm 0,1$ & $2,5 \pm 0,1$ & $3,5 \pm 0,1$ \\
\hline 6. & Титул Дуо & 1,0 & $16,3 \pm 1,4$ & $16,8 \pm 1,4$ & $20,0 \pm 1,8$ & $20,5 \pm 1,8$ & $10,0 \pm 0,8$ & $12,0 \pm 0,8$ & $30,0 \pm 2,6$ & $28,0 \pm 2,6$ \\
\hline 7. & Евіто & 0,7 & $7,5 \pm 0,6$ & $8,0 \pm 0,7$ & $40,0 \pm 3,6$ & $40,5 \pm 3,6$ & $7,5 \pm 6,2$ & $8,0 \pm 6,2$ & $45,0 \pm 4,2$ & $45,0 \pm 4,2$ \\
\hline 8. & Медісон & 1,0 & $10,5 \pm 0,9$ & $11,5 \pm 0,9$ & $40,0 \pm 3,5$ & $40,5 \pm 3,5$ & $5,5 \pm 0,3$ & $6,5 \pm 0,3$ & $40,0 \pm 3,6$ & $40,5 \pm 3,6$ \\
\hline 9. & Абакус & 0,3 & $0,5 \pm 0,01$ & $0,7 \pm 0,01$ & $35,0 \pm 2,6$ & $35,0 \pm 2,5$ & $2,5 \pm 0,1$ & $3,5 \pm 0,2$ & $20,0 \pm 1,7$ & $20,0 \pm 1,7$ \\
\hline 10. & Авіатор Хро & 0,9 & $2,0 \pm 0,1$ & $3,0 \pm 0,4$ & $10,5 \pm 0,8$ & $11,5 \pm 0,9$ & $0,5 \pm 0,02$ & $0,5 \pm 0,02$ & $0,5 \pm 0,02$ & $0,5 \pm 0,02$ \\
\hline 11. & Імпакт T & 0,8 & $0,5 \pm 0,02$ & $1,5 \pm 0,2$ & $10,0 \pm 0,7$ & $11,0 \pm 0,8$ & $0,5 \pm 0,01$ & $0,5 \pm 0,01$ & $5,0 \pm 0,2$ & $5,0 \pm 0,2$ \\
\hline 12. & Імпакт 500 & 0,25 & $0,5 \pm 0,02$ & $1,5 \pm 0,2$ & $7,5 \pm 0,5$ & $8,5 \pm 0,6$ & $3,0 \pm 0,4$ & $4,0 \pm 0,4$ & $15,0 \pm 1,2$ & $16,0 \pm 1,2$ \\
\hline 13. & Ракурс & 0,7 & $0,5 \pm 0,02$ & $0,5 \pm 0,01$ & $2,5 \pm 0,2$ & $2,5 \pm 0,2$ & $0,0 \pm 0$ & $0,0 \pm 0$ & $0,0 \pm 0$ & $0,0 \pm 0$ \\
\hline 14. & Спіріт & 0,7 & $0,5 \pm 0,02$ & $0,5 \pm 0,01$ & $2,0 \pm 0,1$ & $2,5 \pm 0,2$ & $0,0 \pm 0$ & $0,0 \pm 0$ & $0,0 \pm 0$ & $0,0 \pm 0$ \\
\hline 15. & Солігор & 0,8 & $2,5 \pm 0,1$ & $2,8 \pm 0,2$ & $2,0 \pm 0,1$ & $2,0 \pm 0,1$ & $2,5 \pm 0,1$ & $3,5 \pm 0,1$ & $2,5 \pm 0,1$ & $5,5 \pm 0,2$ \\
\hline 16. & Контроль & & $20,0 \pm 1,8$ & $38 \pm 2,6$ & $60,0 \pm 1,8$ & $52,0 \pm 5,3$ & $30,0 \pm 2,8$ & $40,0 \pm 3,1$ & $60,0 \pm 5,7$ & $55,0 \pm 5,2$ \\
\hline
\end{tabular}

Примітка. У таблиці наведені середні значення та стандартні похибки 
3. Біологічна ефективність фунгіцидів проти жовтої іржі на озимій пшениці, посіви 2014 - 2015 та 2013 -2014

pp.

\begin{tabular}{|c|c|c|c|c|c|c|c|c|c|c|c|c|c|c|}
\hline \multirow{4}{*}{$\begin{array}{l}\text { № } \\
\text { 3.П }\end{array}$} & \multirow{4}{*}{ Фунгіциди } & \multirow{4}{*}{$\begin{array}{l}\text { Норма } \\
\text {, л/га }\end{array}$} & \multicolumn{12}{|c|}{ Біологічна ефективність, * \% } \\
\hline & & & \multicolumn{6}{|c|}{ I-варіант } & \multicolumn{6}{|c|}{ II-варіант } \\
\hline & & & \multicolumn{3}{|c|}{$\begin{array}{c}\text { Прапорцевий } \\
\text { листок }\end{array}$} & \multicolumn{3}{|c|}{$\begin{array}{c}\text { Передпрапорцевий } \\
\text { листок }\end{array}$} & \multicolumn{3}{|c|}{$\begin{array}{c}\text { Прапорцевий } \\
\text { листок }\end{array}$} & \multicolumn{3}{|c|}{$\begin{array}{c}\text { Передпрапорцевий } \\
\text { листок }\end{array}$} \\
\hline & & & $\begin{array}{c}2013- \\
2014\end{array}$ & $\begin{array}{c}2014- \\
2015\end{array}$ & $\begin{array}{c}\text { Серед } \\
\text { нє }\end{array}$ & $\begin{array}{c}2013- \\
2014\end{array}$ & $\begin{array}{c}2014- \\
2015\end{array}$ & Середнє & $\begin{array}{l}2013- \\
2014\end{array}$ & $\begin{array}{c}2014- \\
2015\end{array}$ & Середнє & $\begin{array}{l}2013- \\
2014\end{array}$ & $\begin{array}{c}2014- \\
2015\end{array}$ & $\begin{array}{c}\text { Серед } \\
\text { нє }\end{array}$ \\
\hline 1. & Бампер & 1,0 & 75,0 & 85,5 & 80,25 & 91,7 & 87,5 & 89,6 & 48,3 & 58,8 & 53,55 & 16,7 & 10,9 & 13,8 \\
\hline 2. & Суприм 400 & 1,125 & 87,5 & 92,6 & 90,05 & 100,0 & 100,0 & 100 & 91,7 & 91,3 & 91,5 & 91,7 & 89,1 & 90,4 \\
\hline 3. & Вареон & 0,8 & 87,5 & 92,6 & 90,05 & 100,0 & 100,0 & 100 & 81,7 & 83,8 & 82,75 & 93,8 & 91,5 & 92,65 \\
\hline 4. & Аканто Плюс & 1,5 & 100,0 & 98,7 & 99,35 & 99,2 & 98,1 & 98,65 & 98,3 & 98,8 & 98,55 & 91,7 & 90,9 & 91,3 \\
\hline 5. & Старпро & 0,6 & 90,0 & 93,4 & 91,7 & 56,2 & 48,8 & 52,5 & 91,7 & 91,3 & 91,5 & 95,8 & 93,6 & 94,7 \\
\hline 6. & Титул Дуо & 1,0 & 18,5 & 55,8 & 37,15 & 66,7 & 60,6 & 63,65 & 66,7 & 70,0 & 68,35 & 50,0 & 49,1 & 49,55 \\
\hline 7. & Евіто & 0,7 & 62,5 & 78,9 & 70,7 & 33,3 & 22,1 & 27,7 & 75,0 & 80,0 & 77,5 & 25,0 & 18,2 & 21,6 \\
\hline 8. & Медісон & 1,0 & 47,5 & 69,7 & 58,6 & 33,3 & 22,1 & 27,7 & 81,7 & 83,8 & 82,75 & 33,3 & 26,4 & 29,85 \\
\hline 9. & Абакус & 0,3 & 97,5 & 98,2 & 97,85 & 41,7 & 32,7 & 37,2 & 91,7 & 91,3 & 91,5 & 66,7 & 63,6 & 65,15 \\
\hline 10. & Авіатор Хро & 0,9 & 90,0 & 92,1 & 91,05 & 82,5 & 77,9 & 80,2 & 98,3 & 98,8 & 98,55 & 99,2 & 99,1 & 99,15 \\
\hline 11. & Імпакт T & 0,8 & 97,5 & 96,1 & 96,8 & 83,3 & 78,8 & 81,05 & 98,3 & 98,8 & 98,55 & 91,7 & 90,9 & 91,3 \\
\hline 12. & Імпакт 500 & 0,25 & 97,5 & 96,1 & 96,8 & 87,5 & 83,7 & 85,6 & 90,0 & 90,0 & 90 & 75,0 & 70,9 & 72,95 \\
\hline 13. & Ракурс & 0,7 & 97,5 & 98,7 & 98,1 & 95,8 & 95,2 & 95,5 & 100,0 & 100,0 & 100 & 100,0 & 100,0 & 100 \\
\hline 14. & Спіріт & 0,7 & 97,5 & 98,7 & 98,1 & 96,7 & 95,2 & 95,95 & 100,0 & 100,0 & 100 & 100,0 & 100,0 & 100 \\
\hline 15. & Солігор & 0,8 & 87,5 & 92,6 & 90,05 & 96,7 & 96,2 & 96,45 & 91,7 & 91,3 & 91,5 & 95,8 & 90,0 & 92,9 \\
\hline 16. & Контроль & & & & & & & & & & & & & \\
\hline
\end{tabular}

Примітка. * Біологічна ефективність - це результат використання пестицидів у польових умовах, який виражається показниками загибелі, зменшення чисельності шкідливих організмів або міри пошкодження ними рослин, що захищаються 
Аналізуючи урожайність на озимій пшениці (табл. 4) на I варіанті у середньому за два роки нами було помічено, що найвище значення урожайності спостерігалось на варіантах Авіатор Хро 0,9 л/га та Імпакт Т 0,8 л/га i становило 6.6-6.4 т/га.

4. Вплив жовтої іржі на урожайність озимої пшениці у двох варіантах обробки фунгіцидами, посіви 2013 - 2014 та 2014 - 2015 рр.

\begin{tabular}{|c|c|c|c|c|c|c|c|c|}
\hline \multirow{3}{*}{$\begin{array}{c}\text { № } \\
3 . \Pi\end{array}$} & \multirow[b]{3}{*}{ Фунгіциди } & \multirow{3}{*}{$\begin{array}{c}\text { Норма } \\
\text {, л/га }\end{array}$} & \multicolumn{6}{|c|}{ Урожайність,т/га } \\
\hline & & & \multicolumn{3}{|c|}{ I-варіант } & \multicolumn{3}{|c|}{ II-варіант } \\
\hline & & & $\begin{array}{l}2014- \\
2015\end{array}$ & $\begin{array}{c}2013- \\
2014\end{array}$ & $\begin{array}{c}\text { Середнє } \\
\text { за два } \\
\text { роки }\end{array}$ & $\begin{array}{l}2014- \\
2015\end{array}$ & $\begin{array}{c}2013- \\
2014\end{array}$ & $\begin{array}{c}\text { Середнє } \\
\text { за два } \\
\text { роки }\end{array}$ \\
\hline 1. & $\begin{array}{c}\text { Бампер } \\
\text { Супер }\end{array}$ & 1,0 & 6,14 & 6,34 & 6,24 & 5,72 & 5,78 & 5,75 \\
\hline 2. & Суприм 400 & 1,125 & 6,10 & 6,20 & 6,15 & 5,96 & 6,00 & 5,98 \\
\hline 3. & BapeoH & 0,8 & 5,92 & 5,96 & 5,94 & 5,76 & 5,65 & 5,70 \\
\hline 4. & $\begin{array}{l}\text { Аканто } \\
\text { Плюс }\end{array}$ & 1,5 & 6,36 & 6,39 & 6,375 & 6,06 & 6,08 & 6,07 \\
\hline 5. & Старпро & 0,6 & 6,32 & 6,37 & 6,345 & 5,60 & 5,63 & 5,61 \\
\hline 6. & Титул Дуо & 1,0 & 5,92 & 5,94 & 5,93 & 5,86 & 5,87 & 5,86 \\
\hline 7. & Евіто & 0,7 & 6,14 & 6,24 & 6,19 & 6,18 & 6,17 & 6,17 \\
\hline 8. & Медісон & 1,0 & 6,14 & 6,16 & 6,15 & 5,72 & 5,75 & 5,73 \\
\hline 9. & Абакус & 0,3 & 5,84 & 5,88 & 5,86 & 6,10 & 6,14 & 6,12 \\
\hline 10. & Авіатор Хро & 0,9 & 6,66 & 6,62 & 6,64 & 6,16 & 6,18 & 6,17 \\
\hline 11. & Імпакт T & 0,8 & 6,46 & 6,46 & 6,46 & 6,20 & 6,22 & 6,21 \\
\hline 12. & Імпакт 500 & 0,25 & 5,86 & 5,89 & 5,875 & 5,76 & 5,77 & 5,76 \\
\hline 13. & Ракурс & 0,7 & 5,88 & 5,85 & 5,865 & 5,68 & 5,58 & 5,63 \\
\hline 14. & Спіріт & 0,7 & 5,34 & 5,54 & 5,44 & 6,72 & 6,70 & 6,71 \\
\hline 15. & Солігор & 0,8 & 5,74 & 5,64 & 5,69 & 6,24 & 6,34 & 6,29 \\
\hline 16. & \multicolumn{2}{|l|}{ Контроль } & 5,21 & 5,37 & 5,29 & 5,52 & 4,95 & 5,23 \\
\hline & \multicolumn{2}{|l|}{ HIP } & 0,28 & 0,26 & 0,27 & 0,23 & 0,30 & 0,26 \\
\hline
\end{tabular}

Дещо їм поступились варіанти Аканто Плюс 1,5 л/га та Старпро 0,6 л/га, значення урожайності становило 6,3 т/га. На контролі урожайність становила 5,2 т/га. Аналізуючи урожайність на озимій пшениці на II варіанті нами було помічено, що найвище значення урожайності спостерігалось на варіанті Спіріт 0,7 л/га і становило 6,7 т/га, дещо йому поступився варіант Солігор 0,8 л/га (6.29 т/га). На контролі урожайність становила 5,23 т/га.

Висновки i перспективи подальших досліджень. Проаналізувавши ефективність дії досліджуваних препаратів проти жовтої іржі на озимій пшениці у двох варіанта обробки ми визначили наступне. У неепіфтотійні роки жовтої 
іржі варто застосовувати препарати Аканто Плюс 1,5 л/га, Ракурс 0,7 л/га, Спіріт 0,7 л/га, оскільки інтенсивність ураження була мінімальною, а урожайність цьому тим часом найвищою. В епіфітотійні роки жовтої іржі на озимій пшениці варто застосовувати препарати Спіріт 0,7 л/га, оскільки на цьому варіанті уредініоспори були відсутні на рослинах озимої пшениці, а урожайність була максимальною.

\section{Список літератури}

1.Берлянд-Кожевников, В. М. Селекция пшеницы на устойчивость к основным грибным болезням / В. М. Берлянд-Кожевников, М. А. Федин. - М.: Наука, 1977. - 55 с.

2. Бабаянц, Л. Т. Жёлтая ржавчина Puccinia striiformis f. sp. tritici на юге Украины, её расовый состав и сортоустойчивость пшеницы / Л. Т. Бабаянц, О. В. Бабаянц, А. А. Васильев. - Chisinau, 2005. - С. 216-217.

3. Бабаянц, О. В. Основы селекции и метолодогия оценок устойчивости пшеницы к возбудителям болезней / О. В. Бабаянц, Л. Т. Бабаянц. - Одесса. $\mathrm{BMB}, 2014 .-401 \mathrm{c}$.

4. Babayants, O. Yellow rust in the South of Ukraine and resistance of wheat varieties to it in the region / O. Babayants, L. Babayants, N. Chusovitina // $12^{\text {th }}$ International cereal rusts and powdery mildews conference. - Turkey, 2009. - C. 93.

5.Бабаянц, О. В. Імунологічна характеристика рослинних ресурсів пшениці та обгрунтування генетичного захисту від збудників хвороб грибної етіології у Степу України : дис. на здобуття наукового ступеня докт. біол. наук. / О. В. Бабаянц. - Одеса, 2011. - 328 с.

6. Сільськогосподарський портал [Електронний ресурс] / Режим доступу: http://www.agroxxi.ru

7.Бабаянц, Л. Т. Методы селекции и оценки устойчивости пшеницы и ячменя к болезням / Л. Т. Бабаянц, А. Мештерхази, Ф. Вехтер и др. - Прага, 1988. - 321c.

8. Рокицкий, П. Ф. Биологическая статистика / П. Ф. Рокицкий. - Минск, 1973. $-320 \mathrm{c}$.

\section{References}

1.Berlyand-Kozhevnikov, V. M., Fedin, M. A. (1977). Selection of wheat on the sustainability of the bacterium diseases. Moscow, Russia: Science, 55.

2. Babayants, L. T., Babayants, O. V., Vasilyev, A. A. (2005). Yellow rust Puccinia striiformis $f$. sp. tritici in the south of Ukraine, it race composition and varietal resistance of wheat [Materialete Conferintei Nationale (Jubilata) m participare Internationale] Probleme actuale ale geneticii> biotechnologici si amenorarli. - Chisinau, 216-217.

3. Babayants, O. V., Babayants, L. T. (2014). Fundamentals of breeding and methodology of evaluation of wheat resistance to disease pathogenes [Breeding and 
Genetics Institute - National Center of Seed Science and Variety Research]. Odessa, BMB, 401.

4. Babayants, O., Babayants, L., Chusovitina, N. (2009). Yellow rust in the South of Ukraine and resistance of wheat varieties to it in the region [12th International cereal rusts and powdery mildews conference]. Turkey, 93.

5. Babayants, O. V. (2011). Immunological characteristic of plant resources of wheat and reasoning of genetic protection against pathogens fungal etiology in Steppe of Ukraine [Thesis for the Degree of Doctor of Biological Sciences]. Odessa, 328.

6. The agricultural portal. Available at: http: www.agroxxi.ru.

7. Babayants, L. T., Meshterhazy, A., Wechter, F. (1988). Methods of breeding and evaluation of disease resistance of wheat and barley. Prague, 321.

8. Rokytsky, P. F. (1973). Byological statistics. Minsk, 320.

\section{ЭФФЕКТИВНОСТЬ СОВРЕМЕННЫХ ФУНГИЦИДОВ ПРОТИВ ЖЕЛТОЙ РЖАВЧИНЫ (PUCCINIA STRIIFORMIS WEST. F. SP. TRITICI ERIKSS. ET HENN) НА ОЗИМОЙ ПШЕНИЦЕ В ЮЖНОЙ СТЕПИ УКРАИНЫ}

\section{Н. Н. Чусовитина, Л. В. Неплий, М. А. Залогина-Киркелан}

Аннотация. За последние годы на Юге Украины все чаще отмечаются вспышки желтой ржавчины. Основными факторами, которые содействуют развитию болезни - мягкая зима, влажная прохладная весна, проявление болезни в предыдущем году, наличие падалищы, засоренность посевов злаковыми сорняками и, главное, выращивание восприимчивых к желтой ржавчине сортов. Наиболее результативным комплексным мероприятием предупреждения эпифитотий желтой ржавчины является поиск и применение высокоэффективных фунгицидов. При первых проявлениях болезни необходимо их применять с иелью недопущения массового распространения патогена. Высокоэффективные фунгициды, увеличивая урожай зерна, улучшают также и его качество. Анализируя эффективность действия исследуемых препаратов против возбудителя желтой ржавчины на озимой пшенице в двух вариантах обработки было обнаружено, что в не эпифитотийные годы желтой ржавчины стоит применять препараты Аканто Плюс 1,5 л/2, Ракурс 0,7 л/2, Спирит 0,7 л/2, поскольку интенсивность поражения была минимальной, а урожайность при этом наивысшей. В эпифитотийные годы на озимой пшенице стоит применять препараты Спирит 0,7 л/2, поскольку на этом варианте на растениях озимой пшенищы урединиоспоры отсутствовали, а урожайность была максимальной.

Ключевые слова: озимая пшеница, желтая ржавчина, фунгицид, инокулящия 


\title{
THE EFFICIENCY OF MODERN FUNGICIDES AGAINST YELLOW RUST (Puccinia striiformis West. f. sp. tritici Erikss. et Henn) ON WINTER WHEAT IN THE SOUTH OF STEPPE OF UKRAINE N. Chusovitina, L. Nepliy, M. Sologina-Kirkelan
}

\begin{abstract}
In recent years on the South of Ukraine there is flash yellow rust. The main factors that contribute to the development of the disease - mild winter, wet cool spring, manifestation of the disease in the previous year, debris millet crops weed and, importantly, cultivation of susceptible to yellow rust varieties. The most efficient integrated event warning epiphytes yellow rust is the search for and use of highefficiency fungicides. When the first manifestations of the disease need to be applied to prevent the mass dissemination of pathogen. High-efficiency fungicides, increasing the harvest of grain, improve and its quality. In reviewing the effectiveness of the action of drugs against anthrax yellow rust on the winter wheat in two variants processing it was found that in the not epiphytes years yellow rust is to apply the medication Acanto Plus, Angle, Spirit, since the intensity of the destruction was minimal and yield the highest. In epiphytes years the winter wheat is to apply the medication Spirit, since in this version of the plants of winter wheat spores absent as well yield was the maximum.
\end{abstract}

Key words: winter wheat, yellow rust, fungicide, infection 